\title{
Faktor Penentu Tingkat Efisiensi Kinerja Perbankan
}

\author{
${ }^{1 *}$ Sofiana Istinfarani, ${ }^{2}$ Fika Azmi \\ ${ }^{1,2}$ Program Studi Akuntansi STIE Bank BPD Jateng, Indonesia \\ *Email korenpondensi: fixs2002@gmail.com
}

\begin{abstract}
This study aims to examine the determinants of the level of efficiency of banking performance as measured by the non-parametric Data Envelopment Analysis (DEA) method. The determinants of the level of efficiency in banking performance include bank size, Capital Adequacy Ratio, Loan to Deposit Ratio, Non Performing Loans and capitalization. The data in this study were obtained from the Indonesia Stock Exchange (BEI) from 2013 to 2017. The sampling technique used was purposive sampling. The sample used was 160 data from conventional commercial banks in Indonesia. Input variables for calculations using the DEA method are Third Party Funds and Total Assets. While the output variables used are credit distribution and operating income. The results showed that bank size and capitalization did not affect the level of banking efficiency. Meanwhile, Capital Adequacy Ratio and Non-Performing Loans negatifly affect the level of banking efficiency, while the Loan to Deposit Ratio has a positive effect on the level of banking efficiency.
\end{abstract}

Keywords: Banking, DEA, Efficiency, Performance.

Saran sitasi: Istinfarani, S., \& Azmi, F. (2020). Faktor Penentu Tingkat Efisiensi Kinerja Perbankan. Jurnal Akuntansi dan Pajak, 20 (2), 225-235. doi: http://dx.doi.org/10.29040/jap.v20i2.800

DOI: http://dx.doi.org/10.29040/jap.v20i2.800

\section{Pendahuluan}

Perbankan sebagai lembaga keuangan yang menjadi penggerak perekonomian, keberadaannya sangat berperan penting dalam menjaga stabilitas ekonomi suatu Negara. Kinerja yang optimal dalam pengelolaan perbankan menjadi faktor kunci dalam menjaga kesehatan perbankan. Aspek dalam pengukuran kinerjaperbankan yang terpenting dan menjadi fokus utama adalah efisiensi disegala lini untuk menekan biaya operasional. Tingkat efisiensi yang menjadi patokan untuk mengukur kemampuan perbankan dalam mencapai hasil yang maksimal, diukur dari biaya yang dikorbankan dalam kegiatan operasional hingga menghasilkan sesuatu yang diharapkan. Tingkat efisiensi yang rendah mencerminkan adanya pengelolaan biaya yang tidak baik yang dapat menyebabkan kerugian bagi bank.

Efisiensi sering didefinisikan sebagai kemampuan perusahaan dalam menghasilkan output yang maksimal dengan menggunakan input yang minimal. Beberapa isu yang berkembang saat ini di industri perbankan lebih memfokuskan pada efisiensi perbankan. Bahkan, dari berita yang dicuplik dariOtoritas Jasa Keuangan (OJK) melalui surat edaran OJK No. 14/SEOJK.03/2016 menawarkan insentif bagi bank yang beroperasi dengan efisien. Ketua Dekom OJK Muliaman D Hadad, menyebut bahwa insentif akan diberikan pada perbankan yang dapat menurunkan Net Interest Margin (NIM). Insentif tersebut diantaranya diberikan kemudahan dalam membuka kantor cabang dan membuat produk baru. Selain itu, dikutip dari artikel yang diterbitkan oleh Tribun Jogja "Pasca kenaikan suku bunga acuan oleh Bank Indonesia, pihak OJK menghimbau kepada para pelaku industri perbankan untuk memperkecil biaya operasional sehingga perbankan mampu menghindari dampak yang ditimbulkan akibat kebijakan bank sentral tersebut.".

Perlakuan OJK dalam memberikan insentif ini bertujuan untuk menjadikan perbankan di Indonesia menjadi lebih kompetitif dan mampu bersaing di pasar domestik yang besar. Muliaman D Hadad juga menyatakan, jika perbankan mampu meningkatkan efisiensi, maka bank tersebut dapat membuat suku bunga kredit menjadi satu digit, sehingga bank 


\section{Jurnal Akuntansi dan Pajak, 20(02), 2019, 231}

tersebut dapat lebih banyak menyalurkan dananya kepada masyarakat (Setiawan, 2016). Selain itu, semakin berkembangnya teknologi di era digital ini diharapkan bisa menjadi jawaban atas penanganan operasional yang lebih efisien. Seperti penyediaan fasilitas Internet Banking yang terbukti banyak membantu perbankan dalam menekan biaya operasional sehingga bank bisa tumbuh dengan lebih efisien lagi.

Melihat kondisi yang telah diuraikan diatas, perbankan perlu meningkatkan efisiensi operasionalnya agar mampu dalam menghadapi perubahan yang mungkin terjadi. Efisiensi dapat difokuskan untuk meningkatkan kinerja perbankan untuk menghasilkan laba yang optimal melalui peningkatan pendapatan serta penekanan biaya operasional. Faktor penentu yang mempengaruhi tingkat efisiensi perbankan diantaranya adalah ukuran bank, capital adequacy ratio, loan to deposit ratio, non performing loan dan kapitalisasi. Bukti empiris hubungan antara ukuran bank dan efisiensi masih problematik. PenelitianPermana (2015) menyatakan bahwa ukuran bank berpengaruh negatif terhadap tingkat efisiensi perbankan, sedangkan penelitianPerwitaningtyas \& Pangestuti (2015) menyatakan bahwa ukuran bank berpengaruh positif signifikan terhadap tingkat efisiensi perbankan.

Rasio CAR (Capital Adequacy Ratio) merupakan rasio yang menggambarkan kecukupan modal terhadap kecukupan menanggulangi risiko dari total asset yang terdapat pada bank tersebut. Penelitian Ramly \& Hakim (2017) mendapatkan hasil bahwa CAR berpengaruh terhadap efisiensi perbankan. Hubungan yang positif antara rasio CAR dengan tingkat efisiensi perbankan juga pernah ditemukan olehNurwulan (2010), yang dijelaskan melalui keberlangsungan bank yang mempunyai modal besar dan memiliki kemampuan untuk menghasilkan banyak laba. Namun terdapat pula penelitian yang menyatakan bahwa rasio CAR mempunyai pengaruh negatif dengan tingkat efisiensi perbankan (Raharjo, dkk, 2014) .

Rasio LDR (Loan to Deposit Ratio) merupakan rasio yang menggambarkan kinerja fungsi intermediasi perbankan dalam penyaluran kredit. Rasio LDR untuk mengukur rasio kredit yang diberikan terhadap dana yang telah dihimpun. Jika rasio LDR tinggi, itu menandakan bahwa penyaluran kredit semakin banyak dilakukan, sehingga perbankan akan memperoleh laba melalui bunga kredit. Laba yang tinggi dapat menigkatkan efisiensi suatu bank, selama bank tersebut dapat mengelola penyaluran kredit dengan baik. PenelitianMuljawan, dkk (2014) menemukan hubungan yang positif signifikan antara rasio LDR dengan tingkat efisiensi perbankan. Namun hal ini tidak sesuai dengan hasil penelitianRaharjo et al. (2014) yang mendapatkan hasil bahwa rasio LDR berpengaruh negatif terhadap tingkat efisiensi perbankan. Ada pula hasil yang menyatakan bahwa LDR tidak berpengaruh terhadap efisiensi perbankanoleh Perwitaningtyas \& Pangestuti (2015).

Rasio NPL

(Non-Performing

Loan) menggambarkan kualitas pegelolaan kredit, dapat diartikan tingginya rasio NPL menggambarkan rendahnya kualitas pengelolaan kredit yang disalurkan, dan sebaliknya, rendahnya rasio NPL menggambarkan baiknya tingkat pengelolaan kredit yang disalurkan. Kegiatan operasional bank dapat berjalan dengan baik jika mempnyai rasio NPL dibawah 5\%. Jika rasio NPL terlalu tinggi dapat menyebabkan cadangan penyisihan aktiva produktif tidak dapat tercukupi, dan juga dapat berpengaruh terhadap keuntungan dan modal yang dimiliki. Penelitian Raharjo et al., (2014) menyatakan bahwa rasio NPL mempunyai hubungan yang negatif dengan tingkat efisiensi perbankan. Namun hasil penelitian ini berbeda dengan hasil penelitian yang dilakukan oleh Permana (2015) danRamly \& Hakim (2017) yang menyatakan bahwa rasio NPL tidak berpengaruh terhadap tingkat efisiensi perbankan. Hal ini juga berbeda dengan hasil penelitian yang dilakukan olehNurwulan (2010), dimana hasil yang diperoleh yaitu NPL berpengaruh positif terhadap efisiensi perbankan.

Kapitalisasi merupakan kecukupan modal pada suatu bank untuk mengakumulasi aset yang dimiliki oleh bank. Kapitalisasi sangat penting bagi perbankan, karena kapitalisasi digunakan untuk melakukan pembiayaan sekaligus memperkecil risiko Rush Money oleh nasabah. Tingkat rasio kapitalisasi otomatis akan mempengaruhi tingkat efisiensi perbankan. Sehingga semakin tinggi tingkat kapitalisasi maka semakin tinggi pula tingkat efisiensi perbankannya. Hasil penelitian yang dilakukan olehMuljawan et al., (2014) kapitalisasi berpengaruh negatif terhadap efisiensi perbankan, namun hasil penelitian ini tidak sejalan dengan hasil penelitian yang dilakukan olehPermana (2015), yang menyatakan bahwa kapitalisasi tidak berpengaruh terhadap efisiensi perbankan. 


\section{Jurnal Akuntansi dan Pajak, 20(02), 2019, 232}

Dari uraian diatas, tingkat efisiensi perbankan merupakan suatu hal penting dan harus dijaga setiap bank agar dapat beroperasi dengan lebih kompetitif, maka tujuan dalam penelitian ini adalah untuk menganalisis pengaruh ukuran bank, CAR, LDR, NPL dan kapitalisasi terhadap tingkat efisiensi kinerja perbankan.

\section{Konsep Dasar Efisiensi}

Konsep efisiensi merupakan konsep yang mendasar dan lahir dari konsep ekonomi. Efisiensi dapat diarahkan pada pemerolehan hasil dari sejumlah sumberdaya secara optimal. Efisiensi biasa digunakan sebagai suatu ukuran keberhasilan perusahaan dari kegiatan yang dinilai berdasarkan besarnya biaya/sumber daya yang digunakan untuk melampaui target yang ditetapkan. Secara umum, efisiensi menunjukkan pada perbandingan input dan output yang digunakan dalam proses produksi. Jika dalam perbankan, efisiensi menggambarkan salah satu indikator penting dalam penilaian kinerja terbaik suatu bank. Bank dengan kinerja efisiensi maksimal diperkirakan mampu mengimplementasi fungsi intermediasi perbankan secara optimal dan mampu meningkatkan nilai perusahaan.

Efisiensi teknis dan efisiensi alokatif merupakan dua komponen yang ada dalam perusahaan (Asiyah \& Wahyudi, 2014). Pada efisiensi teknis dinyatakan hubungan antara input dan output dalam proses produksi. Efisiensi teknis menggambarkan kapabilitas perusahaan dalam mencapai tingkat output yang maksimum dengan input tertentu. Sedangkan efisiensi alokatif menggambarkan kemampuan perusahaan dalam memaksimalkan penggunaan input yang tersedia dengan struktur harga dan penggunaan teknologi yang tepat. Kombinasi dari kedua ukuran dapat dipakai untuk menghitungefisiensi ekonomi.

\section{Konsep Data Envelopment Analysis (DEA)}

Metode DEA adalah metode non parametik, menggunakan model linear program untuk mengukur antara rasio output dan input dari suatu unit. Metode ini digunakan untuk menguji nilai efisiensi dengan sejumlah input untuk hasil output yang diinginkan, sehingga dapat dijadikan sebagai dasar dalam mengambil keputusan dan digunakan sebagai bahan evaluasi dari perbaikan kinerja (Pratikto, 2011) . Dalam menentukan nilai efisiensi dikatakan sempurna jika nilainya tidak negatif dan berada dikisaran 0 sampai 1. Menurut Muharam \&
Pusvitasari (2015) dalam menganalisis tingkat efisiensi ada dua model yang biasa digunakan, yaitu:

1. Constant Return To Scale (CRS): Nilai pengukuran dalam model ini memiliki batasan yaitu dalam rentang 0 hingga 1 dan nilainya harus positif. Bank dapat dikatakan efisien jika angka rasionya mendekati 1 , jika angka rasio mendekati 0 maka tingkat efisiensi tergolong rendah.

2. Variabel Return To Scale (VRS): Hasil perhitungan dari metode DEA dengan model VRS biasa disebut dengan julukan efisiensi teknik, dengan asumsi variable input dan output berubah. Model yang digunakan dalam penelitian ini yaitu model VRS karena pendekatan fungsi intermediasi, dimana pendekatan ini dapat tercapai apabila bank dapat menghimpun dan menyalurkan dana secara optimal,sertauntuk mengetahui tingkat efisiensi yang sebenarnya.

\section{Pengembangan Hipotesis \\ Pengaruh Ukuran Bank terhadap Tingkat Efisiensi Kinerja Perbankan}

Bank dengan ukuran yang besar memiliki kemampuan yang lebih optimal, beban operasi yang murah dan tangguh dalam menghadapi perubahan kondisi perekonomian (Surifah, 2011) . Ismail et al., (2013) beranggapan besarnya ukuran bank maka bank tersebut mempunyai banyak modal yang dapat diaplikasikan dalam berinvestasi dibidang teknologi untuk menambah pertumbuhan laba dan mengurangi beban operasional. Sementara Muharam \& Pusvitasari (2015) menyatakan bahwa kinerja karyawan dapat dipengaruhi oleh budaya perusahaan yang kuat. Hal ini memiliki arti dimana ukuran perusahaan dijadikan sebagai salah satu faktor yang dapat mempengaruhi kinerja perusahaan.

Penelitian Perwitaningtyas \& Pangestuti (2015) memperoleh hasil dimana ukuran bank berpengaruh dengan tingkat efisiensi perbankan Indonesia. Ukuran bank secara umum diukur dari banyaknya asset yang dimiliki oleh suatuperusahaan dan memiliki peran penting dalam memenuhi kebutuhan operasionalnya, sehingga bank harus memiliki aset dan modal yang cukup besar untuk dapat menjadikan bank tersebut menjadi efisien. Penelitian oleh Nurwulan (2010) dengan proxy Ln Total asset menunjukkan bahwa ukuran perusahaan terdapat pengaruh positif terhadap efisiensi bank. Dari uraian 
Jurnal Akuntansi dan Pajak, 20(02), 2019, 233

diatas, maka penulis merumuskan hipotesis dalam penelitian ini sebagai berikut:

\section{$\mathrm{H}_{1}$ : Ukuran Bank berpengaruh positif terhadap tingkat efisiensi kinerja perbankan.}

\section{Pengaruh CAR terhadap Tingkat Efisiensi \\ Kinerja Perbankan}

Capital Adequacy Ratio (CAR) adalah perhitungan rasio yang mencerminkan kecukupan modal, digunakan sebagai alat ukur dari kemampuan perbankan untuk mengantisipasi kemungkinann dari risiko kerugian. Batas aman dari ratio ini yaitu minimal $8 \%$, rasio ini ditujukan agar dapat menjaga kebutuhan nasabah serta menyetabilkan sistem keuangan secara global. Dengan kata lain, semakin tinggi CAR dapat menggambarkan kinerja perbankan yang optimal dalam menjaga risiko kerugian. Aspek permodalan dapat digunakan untukmeningkatkan kepercayaan masyarakat mengenai dana yang terhimpun dan yang disalurkan oleh pihak bank. Apabila nilai CAR tinggi, memiliki arti bahwa bank dapat memperkecil adanya risiko yang mungkin terjadi.

Aspek permodalan tidak berhenti hanya pada strategi penciptaan sistem perbankan yang sehat, namun juga diterapkan dalam aspek peningkatan efisiensi perbankan. Nurwulan (2010) dalam penelitiannya menyatakan bahwa CAR berpengaruh positif terhadap tingkat efisiensi perbankan, juga menuturkan bahwa CAR digunakan sebagai patokan bank dalam mencukupi modalnya dalam mengukur, mengawasi dan mencegah risiko yang ada karena masih ada pengaruhnya dengan besarnya modal yang dimiliki bank.. Dari penjelasan diatas, maka hipotesis yang dirumuskan yaitu:

$H_{2}$ : CAR berpengaruh positif terhadap tingkat efisiensi kinerja perbankan

\section{Pengaruh LDR terhadap Tingkat Efisiensi Kinerja Perbankan}

Loan to Deposit Ratio (LDR) merupakan rasio untuk mengukur kemampuan bank dalam memenuhi kewajiban jangka pendeknya pada saat ditagih dengan melihat perbandingan antara total aktiva lancar dengan kewajiban lancarnya. Hal ini bisa dikatakan dengan menjaga kestabilan dari tingkat likuiditas bank. Likuiditas bank harus diolah dengan baik agar selalu bisa mencukupi kebutuhan nasabah pada saat diperlukan. Rasio LDR yang tinggi memiliki arti bahwa besarnya dana yang disalurkan dalam perkreditan, perbankan tersebut akan memperoleh laba dari bunga kredit yang akhirnya akan menambah tingkat efisiensi perbankan selama bank tersebut dapat mengelola manajemen kredit yang diberikan kepada masyarakat dengan baik. Namun, jika DPK yang dihimpun bank tidak diputar menjadi kredit, maka dana tersebut akan menjadi pengendapan uang yang akan berakibat pada hilangnya kesempatan mendapatkan pendapatan namun tetap menambah beban bagi bank dalam kewajiban memberikan pengorbanannya dalam bentuk beban bunga kepada nasabah.

Hasil penelitian dariMuljawan et al., (2014) dimana dalam penelitiannya didapatkan adanya hubungan positif signifikan antara LDR dengan tingkat efisiensi perbankan. Semakin tinggi LDR maka tingkat efisiensi bank akan semakin besar. Berdasarkan uraian diatas, maka hipotesis yang diajukan :

\section{$H_{3}$ : LDR berpengaruh positif terhadap tingkat efisiensi kinerja perbankan.}

\section{Pengaruh NPL terhadap Tingkat Efisiensi Kinerja Perbankan}

Non performing loan (NPL) dipakai sebagai proksi dari kualitas pengelolaan kredit. NPL merupakan rasio yang membandingkan antara pembiayaan yang bermasalah, dengan total pembiayaan yang diberikan, jika prosentasenya diatas 5\%, maka akan berpengaruh terhadap kesehatan bank. NPL yang tinggi menyebabkan munculnya biaya yang harus dikorbankan, seperti pengeluaran biaya untuk memperoleh kepercayaan publik, menurunnya deposito karena kinerja bank yang jelek dan biaya tambahan untuk mengawasi kualitas kredit. Peningkatan biaya - biaya tidak bernilai tambah akan menurunkan efisiensi perbankan, sehingga semakin tinggi non performing loan maka semakin rendah efisiensi perbankan.

Beberapa studi empiris membuktikan bahwa bank akan berada dititik efisien apabila bank tersebut memiliki tingkat NPL yang rendah. Hasil penelitian yang diperolehMuazaroh et al., (2012) yang menyatakan bahwa NPL berpengaruh negatif terhadap efisiensi perbankan namun tidak signifikan. Seperti hasil yang diperoleh dari penelitianRaharjo et al., (2014) bahwa LDR berpengaruh negatif terhadap tingkat efisiensi bank. Berdasarkan uraian diatas, maka hipotesis yang dirumuskan yaitu :

$\mathrm{H}_{4}$ : NPL berpengaruh negatif terhadap tingkat efisiensi kinerja perbankan 


\section{Jurnal Akuntansi dan Pajak, 20(02), 2019, 234}

\section{Pengaruh Kapitalisasi terhadap Tingkat Efisiensi Kinerja Perbankan}

Kapitalisasi menunjukkan kecukupan modal yang dimiliki bank untuk mengakumulasikan asset yang dimiliki. Besarnya tingkat kapitalisasi dapat mencerminkan ukuran yang dimiliki bank. Kapitalisasi pasar merupakan nilai dari perusahaan yang dihitung dari harga pasar saham dikalikan dengan jumlah saham yang telah beredar. Hubungan antara kapitalisasi pasar dengan efisiensi bank adalah positif bilamana pasar modal dan pihak bank saling berhubungan dengan baik, disisi lain dapat berubah menjadi hubungan yang negatif jika keduanya saling bersaing.

Tingkat rasio kapitalisasi yang akan langsung berpengaruh pada tingkat efisiensi ini berartibahwa tingkat kapitalisasi yang tinggi akan membuat tingkat efisiensi yang tinggi pula. Seperti hasil penelitian dariPermana (2015) bahwa hubungan antara kapitalisasi dengan efisiensi bank yaitu berpengaruh positif. Sejalan dengan hasil penelitian yang dilakukan olehZikiri (2017) dimana dalam penelitiannya kapitalisasi memiliki pengaruh positif terhadap efisiensi. Dengan penjelasan mengenai kapitalisasi diatas, penulis menyimpulkan hipotesis yang akan diajukan yaitu:

\section{$\mathrm{H}_{5}$ : Kapitalisasi berpengaruh positif terhadap kinerja perbankan}

\section{Model Penelitian}

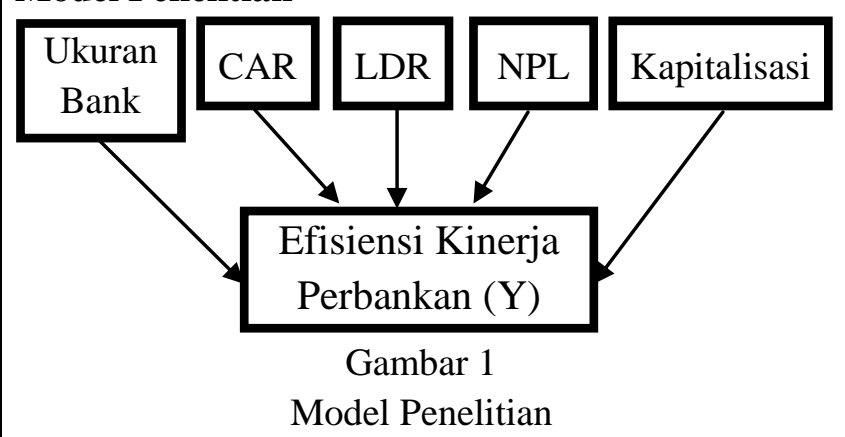

\section{Metode Penelitian}

\section{Populasi dan Sampel}

Populasi yang dipakai pada penelitian ini adalah bank umum konvensional yang terdaftar di Bursa Efek Indonesia periode 2013 - 2017. Metode pengambilan sampel yang digunakan adalah metode purposive sampling, dimana populasi yang dijadikan sampel penelitian adalah populasi yang memenuhi kriteria sampel tertentu. Kriteria dalam pengambilan sampel adalah:

1. Bank umum konvensional yang secara konsisten terdaftar sebagai bank di Bursa Efek
Indonesia dan mempublikasi laporan tahunan dalam periode tahun 2013 - 2017.

2. Bank umum konvensional yang melaporkan laporan keuangan dan catatan atas laporan keuangan tahun 2013 - 2017.

3. Bank umum konvensional yang terdaftar di Bursa Efek Indonesia yang mempunyai data lengkap yang dibutuhkan dalam penelitian ini.

\section{Metode Pengumpulan Data dan Sumber Data Penelitian}

Metode pengambilan data dalam penelitian ini yaitu metode dokumentasi dikarenakan data berupa data sekunder yang terdapat di dalam annual report perusahaan yang diambil untuk sampel penelitian. Penelitian ini menggunakan data skunder cross section berupa data laporan keuangan dari perusahaan perbankan yang menjadi sampel yang telah diaudit dan dipublikasikan. Data sekunder merupakan data yang diperoleh dari pihak lain. Data sekunder biasanya berupa catatan, bukti, atau laporan historis yang tersusun dalam arsip maupun dipublikasikan. Data utama penelitian diambil dari Bursa Efek Indonesia. Data pendukungnya dikumpulkan dari berbagai sumber, seperti jurnal, penelitian sebelumnya, internet dan lain-lain. Objek materi dari penelitian ini adalah data-data inputoutput perbankan umum di Indonesia, yang mana kemudian diolah untuk memperoleh hasil nilai efisiensi untuk masing-masing bank umum di Indonesia dari tahun 2013 sampai tahun 2017.

\section{Variabel Input}

1. Dana Pihak Ketiga (DPK) : Dana pihak ketiga merupakan dana yang dihimpun dari masyarakat yang kelebihan dana dalam mata uang rupiah maupun dalam valuta asing. Dalam bank, DPK ini merupakan dana yang paling besar yang dimiliki bank. Hal ini berbanding lurus dengan fungsi utama bank sebagai penghimpun dana dari masyarakat. Adapun perhitungan DPK adalah sebagai berikut:

$$
\text { DPK }=\text { Giro }+ \text { Tabungan }+ \text { Deposito }
$$

2. Total Asset: Asset merupakan harta atau kekayan yang berwujud maupun tidak berwujud, dapat bergerak maupun tidak bergerak yang dimiliki oleh suatu organisasi. Asset memiliki jenis yang bisa dibagi menjadi beberapa kategori, yaitu asset lancer, asset tetap dan asset tak berwujud. Jika dituliskan dalam rumus:

Total asset $=$ aktiva tetap + aktiva lancar 


\section{Variabel Output}

\section{Jurnal Akuntansi dan Pajak, 20(02), 2019, 235}

1. Kredit: Kredit merupakan fungsi utama bank yang digunakan sebagai penyaluran dana kepada pihak yang kekurangan dana, dimana dalam transaksi kredit terdapat kesepakatan pinjam meminjam antara pemberi kredit (bank) dengan pihak lain (peminjam) yang wajib untuk melaksanakan dengan jumlah bunga sebagai imbalan. Perhitungannya bisa dilihat dari:

Kredit $=$ Total kredit yang disalurkan

2. Pendapatan Operasional: Pendapatan operasional merupakan pendapatan yang diperoleh perusahaan sebagai hasil dari usaha pokok perusahaan dan pendapatan tersebut telah benar-benar diterima. Penentuan pendapatan operasional yaitu menentukan biaya operasional yang dibutuhkan kemudian menguranginya dengan pendapatan operasional brutonya.

$\mathrm{PO}=$ Jumlah pendapatan operasional - Beban operasional

\section{Variabel Dependen}

Tingkat Efisiensi Perbankan: Efisiensi perbankan menjadi salah satu indikator kinerja perbankan. Efisiensi perbankan merupakan indikator untuk mengukur seluruh kinerja dari aktivitas perbankan. Pengukuran efisiensi dengan metode ini dapat dilakukan dengan menggunakan pendekatan regresi dengan fungsi:

$$
\mathrm{Y}=\mathrm{f}(\mathrm{X} 1, \mathrm{X} 2, \mathrm{X} 3, \mathrm{X} 4 \ldots . . \mathrm{Xn})
$$

\section{Variabel Independen}

1. Ukuran Bank: Ukuran bank merupakan salah satu karakteristik bank yang umumnya menjadi determinan dari efisiensi perbankan. Bank berukuran besar umumnya memiliki keunggulan daripada bank berukuran sedang atau kecil. Dihitung dengan logaritma natural dari total asset, dengan rumus:

Ukuran perbankan $=\mathrm{Ln} \times$ Total Aset

2. Current Adequacy Ratio (CAR) : Rasio Capital Adequacy Ratio (CAR) menunjukan kecukupan modal atas risiko total aset bank tersebut. CAR juga dianggap sebagai faktor yang dapat mempengaruhi tingkat efisiensi bank. Dihitung dengan rumus:

$$
\mathrm{CAR}=\frac{\text { Modal }}{\operatorname{ATMR} *} \times 100 \%
$$

3. Loan to Deposite Ratio (LDR) : Loan to deposit ratio (LDR) merupakan rasio yang digunakan untuk mengukur kinerja fungsi intermediasi perbankan dalam menyalurkan kredit. LDR disebut juga rasio kredit terhadap total DPK yang digunakan untuk mengukur dana yang disalurkan dalam bentuk kredit. Banyaknya dana yang disalurkan untuk pembiayaan kredit, berarti bank semakin lebih efisien dalam kegiatan operasional. Dihitung dengan rumus:

$$
\text { LDR : } \frac{\text { Kredityangdiberikan }}{\text { Danayangditerima }} \times 100 \%
$$

4. Non Performing Loan (NPL) : Non performing loan dipakai sebagai proksi dari kualitas pengelolaan kredit. Bank dapat mennjalankan operasionalnya dengan baik apabila mempunyai NPL di bawah 5\%. NPL yang tinggi dapat menyebabkan ketidakefisienan di perbankan. Berger \& Young (1997) mengungkapkan bahwa ketika pinjaman kredit (loan) telahmelewati jatuh tempo, bank harus mengeluarkan biaya - biaya tambahan terkaitdengan penanganan masalah kredit macet tersebut. Dihitung dengan rumus:

NPL: $\frac{\text { PenyisihanPenghapusanAktivaProduktif (PPAP) }}{\text { TotalPembiayaan }} \times 100$

5. Kapitalisasi: Kapitalisasi merupakan nilai pasar yang diberikan kepada perusahaan, dengan melihat kapitalisasi pasar secara sepintas maka kita dapat mengetahui perusahaan mana yang memiliki ukuran yang besar. Kapitalisasi pasar yang besar biasanya memiliki ukuran perusahaan yang lebih besar dibandingkan dengan perusahaan dengan kapitalisasi pasar yang kecil. Dihitung dengan rumus:

$$
\begin{aligned}
\text { Kapitalisasi }= & \text { Harga saham di pasar x Seluruh } \\
& \text { saham perusahaan }
\end{aligned}
$$

\section{Metode Analisis}

Metode dalam penelitian ini menggunakan DEA yaitu sebuah metode frontier non parametric yang membandingkan nilai rasio input dan output dalam sebuah populasi. Perhitungan dengan metode DEA bertujuan untuk mengetahui tingkat efisiensi dari DMU terhadap bank sejenis. Metode ini juga bisa dipakai untuk mengevaluasi kinerja dari hasil tingkat efisiensi dari objek yang diteliti. Setiap UKE memiliki perpaduan untuk mencerminkan keragaman input yang untuk menghasilkanoutput yang berbeda. Menurut (Muharam \& Pusvitasari, 2015) nilai efisien dapat ditentukan apabila nilai dualnya sama dengan 1 (nilai efisiensi 100\%), namun apabila nilai dualnya kurang dari 1 maka UKE tersebut dianggap tidak efisien. Dalam 
penelitian ini Software yang digunakan adalah WDEA (Warwick Data Envelopment Analysis) dan SPSS.

Dalam penelitian ini pengukuran tingkat efisiensi menggunakan pendekatan intermediasi karena bank sebagai lembaga intermediator, dimana dalam pelaksanaanya bank bertindak untuk menghimpun dana dari pihak yang kelebihan dan menyalurkan dananya pada pihak yang membutuhkan dana. Variabelinput yang digunakan adalah dana pihak ketiga dan total asset, sedangkan outputnya kredit yang disalurkan dan pendapatan operasional. Sedangkan konsep data yang digunakan yaitu dengan Variabel Return to Scale (VRS). Model ini dipakai karena menyesuaikan dengan pendekatan yang digunakan, yaitu intermediasi, dimana pendekatan ini dapat tercapai apabila bank dapat menghimpun dan menyalurkan dana secara optimal. Selain itu model ini dapat mengetahui tingkat efisiensi yang sebenarnya.

\section{Uji Regresi Linier Berganda}

Menurut Hidayat (2018) Uji Regresi linier berganda merupakan uji yang menggunakan variabel bebas lebih dari satu. Adapun Model regresi linear berganda digambarkan dengan persamaan sebagai berikut:

$\mathrm{Y}=\alpha+\beta 1 \mathrm{X} 2+\beta 2 \mathrm{X} 2+\beta \mathrm{n} \mathrm{Xn}+\mathrm{e}$

Keterangan:

$\mathrm{Y}=$ Variabel terikat atau response.

$\mathrm{X}=$ Variabel bebas atau predictor.

A $\quad=$ Konstanta.

$\beta \quad=$ Slope atau Koefisien estimate.

\section{Hasil Penelitian dan Pembahasan}

\subsection{Hasil Penelitian}

Objek dari penelitian ini adalah bank umum konvensional yang terdaftar di BEI dan memiliki laporan keuangan yang dipublikasikan periode tahun 2013 - 2017 dan sebagian dari website masingmasing bank. Penelitian menggunakan data sekunder berupa laporan keuangan bank. Data penelitian ini diperoleh sebanyak 32 bank yang masuk kedalam kriteria dalam pengambilan data sampel. Dengan demikian data sampel pengamatan yang digunakan sebanyak $5 \times 32=160$ data pengamatan.

Statistik deskriptif untuk keseluruhan data dari penelitian ini didapat dari pengamatan data rangkuman kinerja bank umum konvensional yang terdaftar di BEI dari periode 2013 - 2017 ditunjukkan sebagai berikut:
Tabel 1

Statistik Deskriptif

\begin{tabular}{|l|r|r|r|r|r|}
\hline & N & Minimum & Maximum & Mean & $\begin{array}{c}\text { Std. } \\
\text { Deviation }\end{array}$ \\
\hline Ukuran Bank & 160 & 27.8819 & 34.6577 & 31.422761 & 1.6636042 \\
CAR & 160 & 10.44 & 37.17 & 18.8261 & 4.60951 \\
LDR & 160 & 42.02 & 140.72 & 85.4700 & 13.77175 \\
NPL & 160 & .00 & 15.82 & 2.4167 & 2.00632 \\
LnMCAP & 160 & 23.4259 & 33.9225 & 29.418448 & 2.0468791 \\
EFFICIENCY & 160 & 58.23 & 100.00 & 87.8075 & 10.70050 \\
Valid N & 160 & & & & \\
(listwise) & & & & & \\
\hline
\end{tabular}

Sumber: Data sekunder yang diolah.

Tabel 1 menunjukkan gambaran secara umum statistik deskriptif variabel yang terkait, diantaranya:

1. Ukuran Bank: Variabel ukuran bank yang diukur dengan menggunakan logaritma natural dari total aset diperoleh rata-rata sebesar 31,42. Dapat dilihat bahwa rata-rata perusahaan sampel memiliki ln total aset adalah sebesar 31,42. Nilai minimum ukuran perusahaan sebesar 27,8819, sedangkan nilai maksimum sebesar 34,66.

2. CAR: Rata-rata CAR pada bank umum selama periode penelitian diperoleh sebesar 18,83\%. Hasil ini memperlihatkan bahwa bank sampel memiliki kecukupan modal minimal sebesar $8 \%$ sebagaimana ditetapkan oleh Bank Indonesia. Nilai CAR terendah adalah sebesar 10,44 dan CAR tertinggi adalah sebesar 37,17.

3. LDR: Selama periode penelitian rata-rata LDR diperoleh sebesar $85,47 \%$. Hal ini berarti bahwa pembiayaan bank sampel mencapai $85,47 \%$ dibanding dengan deposit atau dana yang dihimpun dari masyarakat. LDR terendah adalah sebesar $42,02 \%$ sedangkan LDR tertinggi adalah sebesar $140,72 \%$ dengan standar deviasi sebesar 13,771.

4. NPL: Rata-rata NPL selama periode penelitian tahun 2013 hingga 2017 adalah sebesar $2,4167 \%$. Hal ini berarti bahwa besarnya ratarata pendanaan bermasalah yang dimiliki bank adalah mencapai $2,42 \%$ dari seluruh pendanaan yang dilakukan oleh bank. Nilai NPL tertinggi adalah sebesar $15,82 \%$ dan NPL terendah adalah sebesar $0,00 \%$. Sedangkan standar deviasi NPL diperoleh sebesar 2,0063

5. Kapitalisasi: Variabel kapitakisasi pasar bank yang dihitung dengan mengalikan antara jumlah saham yang beredar dengan harga saham dipasaran sehingga diperoleh rata-rata sebesar 


\section{Jurnal Akuntansi dan Pajak, 20(02), 2019, 237}

29,42. Hal ini menunjukkan bahwa rata-rata perusahaan sampel memiliki ln kapitalisasi aset sebesar 29,42. Nilai minimum kapaitalisasi sebesar 23,43, sedangkan nilai maksimum sebesar 33,92.

6. Efisiensi Bank: Efisiensi bank mencerminkan rasio antara output dan input yang diproleh bank dalam menjalankan usahanya. Efisiensi ini dihitung dengan menggunakan DEA. Rata-rata Efisiensi pada bank umum selama periode penelitian diperoleh sebesar $87,81 \%$. Efisiensi terendah adalah sebesar 56,23 sedangkan Efisiensi tertinggi adalah sebesar $110 \%$.

\section{Analisis Regresi Linier Berganda}

Dalam penelitian ini, analisis jalur dipakai untuk menguji hipotesis mengenai variabel bebas secara parsial maupun simultan terhadap variabel terikat. Perhitungan ini memakai alat statistis SPSS. Hasil pengolahan data dijelaskan pada tabelberikut ini:

Tabel 2

Hasil Analisis Regresi Linier Berganda

\begin{tabular}{|l|r|r|r|r|r|}
\hline \multirow{2}{*}{ Model } & \multicolumn{2}{|c|}{$\begin{array}{c}\text { Unstandardized } \\
\text { Coefficients }\end{array}$} & $\begin{array}{c}\text { Standardized } \\
\text { Coefficients }\end{array}$ & \multirow{2}{*}{ T } & \multirow{2}{*}{ Sig. } \\
\cline { 2 - 4 } & \multicolumn{1}{|c|}{$\mathrm{B}$} & \multicolumn{1}{c|}{$\begin{array}{c}\text { Std. } \\
\text { Error }\end{array}$} & \multicolumn{1}{|c|}{ Beta } & & \\
\hline (Constant) & 71.312 & 10.915 & & 6.533 & .000 \\
Ukuran Bank & -.519 & .456 & -.081 & -1.139 & .257 \\
CAR & -.508 & .120 & -.219 & -4.248 & .000 \\
LDR & .594 & .040 & .765 & 15.039 & .000 \\
NPL & -1.005 & .264 & -.188 & -3.812 & .000 \\
LnMCAP & -.204 & .366 & -.039 & -.557 & .578 \\
\hline
\end{tabular}

Model persamaan yang dapat dituliskan dari hasil tersebut dalam bentuk persamaan sebagai berikut:

$\mathrm{EFF}=71,312-0,519$ Ukuran Bank $-0,508 \mathrm{CAR}+$ 0,594 LDR - 1,005 NPL - 0204 :nMACAP + e1

Hasil tersebut dapat dijelaskan sebagai berikut :

1. Koefisien jalur variabel Ukuran bank memiliki arah koefisien negatif berarti bahwa bank yang memiliki aset besar cenderung memiliki efisiensi yang lebih rendah.

2. Koefisien jalur variabel CAR memilikiarah koefisien negatif berarti bahwa bank dengan CAR yang tinggi cenderung memiliki efisiensi yang lebih rendah.

3. Koefisien jalur variabel LDR memiliki arah koefisien positif berarti bahwa bank dengan LDR yang tinggi cenderung memiliki efisiensi yang lebih tinggi.
4. Koefisien jalur variabel NPL memiliki arah koefisien negatif yang berarti bahwa bank dengan rasio NPL tinggi cenderung memiliki efisiensi yang lebih rendah.

5. Koefisien jalur variabel Kapitalisasi bank memiliki arah koefisien negatif berarti bahwa bank dengan kapitalisasi yang besar cenderung memiliki efisiensi yang lebih rendah.

\subsection{Pembahasan}

\section{Pengaruh Ukuran BankTerhadap Tingkat Efisiensi Kinerja Perbankan}

Berdasarkan hasil perhitungan pada tabel 2 bank umum konvensional dari periode 2013 sampai dengan 2017 memiliki rata-rata sebesar 31,42. Dapat diketahui dimana ukuran bank merupakan gambaran dari besar kecilnya perusahaan yang dilihat dari berbagai macam, seperti log natural nilai saham, log natural total asset, jumlah tenaga kerja, dll. Hasil pengujian Independent $t$-test pada tabel 2didapatkan nilai $t$ hitung pada variabel ukuran bank terhadap efisiensi menunjukkan nilai $\mathrm{t}$ hitung $=-1,139$ dan nilai signifikansi sebesar $0,257>0,05$.Dengan demikian diperoleh bahwa ukuran bank tidak memiliki pengaruh terhadap efisiensi. Oleh karena itu,hipotesis 1 yang menyatakan bahwa ukuran bank berpengaruh positif terhadap efisiensi kinerja perbankan ditolak. Hasil penelitian ini sejalan dengan hasil penelitian dariPermana (2015), yang menyatakan bahwa pengaruh ukuran bank terhadap tingkat efisiensi perbankan tidak linear.

Ukuran bank merupakan indikator yang digunakan untuk menggolongkan bank pada golongan besar, kecil maupun menengah. Ukuran bank diukur dengan berdasarkan total asset yang dimiliki bank. Bank dengan ukuran besar memiliki banyak keuntungan dibandingkan bank dengan ukuran yang kecil. MenurutOktavianti (2015) contoh keuntungan yang didapatkan bank besar yaitu bank memiliki kemudahan untuk menghimpun dana dari pasar modal, terlebih bank yang besar memiliki kekuatan lebih dalam tawar menawar mengenai transaksi kontrak keuangan, kemudian keuntungan selanjutnya yaitu bank yang besar lebih mudah untuk memperoleh laba karena adanya pengaruh dari skala biaya dan return.

Namun berdasarkan pengujian hipotesis dalam penelitian ini, ukuran bank tidak berpengaruh terhadap efisiensi kinerja bank. Total asset yang dimiliki bank tidak cukup untuk dapat mencerminkan bahwa bank tersebut bisa 


\section{Jurnal Akuntansi dan Pajak, 20(02), 2019, 238}

menjalankan kegiatan operasional dengan efisien. Kepemilikan asset yang besar tidak menjamin bahwa bank tersebut bisa lebih efisien dibandingkan dengan bank yang memiliki total asset yang lebih kecil. Hal ini dapat terjadi jika dalam pengelolaan asset tidak optimal dan banyak melakukan pengeluaran yang tidak penting. Sehingga banyak mengeluarkan biaya dan menjadikan bank tersebut tidak efisien. Pada dasarnya, berapapun asset yang dimiliki bank dapat menjadikannya efisien apabila dikelola dengan baik sesuai dengan kebutuhan yang diperlukan dan memanfaatkan asset yang ada dengan lebih optimal.

\section{Pengaruh CAR Terhadap Tingkat Efisiensi Kinerja Perbankan}

Berdasarkan keputusan yang dibuat Bank Indonesia, minimal penyediaan modal minimum yaitu $8 \%$. Semakin besar rasio CAR, maka semakin aman dana yang diperoleh dari deposan pada bank tersebut. Berdasarkan tabel1 rasio CAR bank sampel memiliki rata - rata $18.82 \%$. Hal ini memiliki pengertian bahwa modal minimum yang disediakan bank umum konvensional yang terdaftar di BEI dari periode tahun 2013 - 2017 untuk mengantisipasi risiko pasar dan kredit adalah sebesar $18,82 \%$ dari total modal yang dimiliki. Hasil perhitungan deskriptif rasio CAR apabila ditinjau dari analisis kesehatan, bank umum konvensional dapat menyediakan modal minimumnya termasuk dalam kategori sangat sehat, karena hasil minimumnya pun masih diatas $8 \%$ yaitu $10,44 \%$ dan memiliki hasil maksimal $37,77 \%$. Sedangkan dalam hasil uji Independent t-test pada tabel 2 menunjukkan bahwa nilai t hitung untuk variabel CAR terhadap Efisiensi didaptkan nilai $\mathrm{t}$ hitung $=-4,248$ dan nilai signifikansi sebesar $0,000<0,05$.Dengan demikian diperoleh bahwa CAR berpengaruh negatifterhadap efisiensi bank. Oleh karena itu, hipotesis 2 yang menyatakan CAR berpengaruh positif terhadap efisiensi kinerja perbankan ditolak.

Hasil penelitian ini sejalan olehRaharjo et al., (2014) yang memperoleh hasil bahwa CAR berpengaruh negatif tehadap efisiensi kinerja bank. Kecukupan modal yang bank umum konvensional berada pada kriteria yang baik. Namun berdasarkan uji Independent t-test menunjukkan bahwa nilai signifikansi dari CAR memiliki pengaruh negatif terhadapefisiensi kinerja perbankan. Sehingga dapat disimpulkan bahwa CAR dapat mempengaruhi tingkat efisiensi kinerja perbankan secara negatif, yang mengandung arti bahwa tingkat CAR yang tinggi tidak menjamin suatu bank dapat berjalan dengan efisien. Dalam arti yang lain, semakin tinggi CAR, efisiensi bank akan turun. Semua dapat terjadi akibat buruknya pengelolaan manajemen dalam suatu bank. CAR yang tinggi menunjukkan modal bank yang semakin besar atau ATMR yang kecil. Hal ini berarti bank semakin sedikit dalam penyaluran kreditmya, akibatnya efisiensi dalam penyaluran lreditpun akan semakin turun. Sehingga dapat disimpulkan bahwa CAR berpengaruh terhadap tingkat efisiensi perbankan namun dengan koefisien negatif.

Aspek terpenting dalam menjaga efisiensi bank adalah permodalan. Modal menjadi awal terbentuknya sebuah bank. Aspek modal dapat dilihat dari rasio CAR, yang dapat menggambarkan kekuatan bank dalam melindungi para pemilik dana melalui permodalannya. CAR adalah rasio kecukupan modal, yaitu kewajiban dalam menyediakan modal minimum kewajiban (KPMM) yang harus selalu dikontrol setiap bank sebagai keseimbangan darimodal dan total aset bank.Kepercayaan merupakan hal yang sangat penting yang arus dimiliki oleh bank untuk dapat menjalankan kegiatan operasionalnya dalam masyarakat. Sebesar apapun modal bank namun tidak mendapatkan rasa percaya dari pengelolaan manajemen bank tersebut, maka bank tidak akan dapat berjalan sebagaimana mestinya. Lain halnya dengan bank yang sudah mendapat kepercayaan dari masyarakat, mereka akan menyalurkan dananya pada bank sehingga pihak bank dapat menjalankan operasionalnya tanpa adanya gangguan dari persoalan modal. Oleh karena itu, manajemen bank harus senantiasa menjaga dan terus membangun kepercayaan masyarakat terhadap bank, sehingga kinerja bank akan terus meningkat.

\section{Pengaruh LDR Terhadap Efisiensi Kinerja Perbankan}

Menurut peraturan Bank Indonesia, LDR yang baik adalah sebesar $85-110 \%$. Apabila dilihat dalam tabel 2 bahwa rata - rata rasio LDR bank umum konvensional yang terdaftar di BEI adalah sebesar $85,47 \%$. Hal ini berarti bahwa bank sampel dalam menyalurkan kredit mengindikasikan bank yang likuid dengan menyalurkan kreditnya karena memiliki kapasitas dana yang tersedia sehingga dapat disalurkan dalam bentuk kredit. Hasil uji Independent $t$-test pada tabel2didapatkan nilai $\mathrm{t}$ 


\section{Jurnal Akuntansi dan Pajak, 20(02), 2019, 239}

hitung untuk variabel LDR terhadap Efisiensi adalah nilai t hitung $=15,039$ dan nilai signifikansi sebesar $0,000<0,05$.Dengan demikian diperoleh bahwa LDR berpengaruh positif terhadapEfisiensi. Oleh karena itu,hipotesis 3 yang menyatakan LDR berpengaruh positif terhadap efisiensi kinerja bank diterima.Hasil penelitian ini didukung dengan hasil penelitianMuljawan et al., (2014) yaitu terdapat hubungan positif antara LDR dengan tingkat efisiensi perbankan. Artinya, tingginya nilai rasio LDR menunjukkan banyaknya dana yang disalurkan dalam perkreditan dan memperoleh laba dari bunga kredit yang dapat meningkatkan efisiensi perbankan.

Likuiditas adalah kemampuan bank untuk menyalurkan simpanan yang dihimpun dan menyalurkan kredit kepada masyarakat. Kemampuan bank untuk menyalurkan besarnya kredit ini diproksikan dengan rasio LDR. Semakin besar LDR berarti semakin tinggi kredit yang disalurkan dan dapat meningkatkan keuntungan, namun mempunyai resiko yang tinggi. Apabila bank mampu untuk menjaga likuiditasnya, maka loyalitas kepercayaan masyarakat kepada bank akan semakin tinggi. Apabila loyalitas dari masyarakat tinggi maka bank dapat bersaing kompetitif dengan bank lain dan efisiensi bank juga akan meningkat.

\section{Pengaruh NPL Terhadap Efisiensi Kinerja Perbankan}

Berdasarkan keputusan Bank Indonesia, NPL yang baik adalah sebesar $2 \%-5 \%$. Berdasarkan tabel 2, NPL bank umum konvensional yang terdaftar di BEI memiliki rata - rata sebesar $2,41 \%$. Hal ini memiliki pengertian bahwa kolektivitas aset kredit bank umum konvensional berada pada kategori yang baik. Sehingga kredit bermasalah yang ditimbulkan akan semakin rendah. Apabila ditinjau dari analisis kesehatan bank, kelompok bank umum konvensional ini menunjukkan kualitas aset kredit yang kolektible bahkan termasuk dalam kategori sangat sehat yaitu $2 \%-5 \%$.

Hasil uji Independent t-test pada tabel2didapatkan nilai $\mathrm{t}$ hitung untuk variabel NPL terhadap Efisiensi yaitu nilai $\mathrm{t}$ hitung $=-3,812$ dan nilai signifikansi sebesar $0,000<0,05$.Dengan demikian diperoleh bahwa NPL memiliki pengaruh negatif terhadapefisiensi bank. Oleh karena itu,hipotesis 4 yang menyatakan bahwa NPL berpengaruh negatif terhadap efisiensi kinerja perbankan diterima.Hasil penelitian ini didukung oleh penelitianRaharjo et al., (2014) yang menyatakan bahwa NPL berpengaruh negatif terhadap efisiensi perbankan,artinya tingkat efisiensi kinerja bank akan terus meningkat apabila nilai rasio LDR rendah. Dalam hal ini berarti kinerja perbankan dalam mengelola pinjaman sudah cukup baik, sehingga bank tidak perlu mengeluarkan biaya tambahan untuk menangani masalah kredit yang tidak lancar. Dengan demikian, bank dapat mencapai tingkat efisiensi kinerja perbankan.

Non-Performing Loan (NPL) digunakan sebagai proksi dari kualitas aset kredit bank. Rasio ini menunjukkan kualitas aset kredit yang jika kolektibilitasnya kurang lancar, diragukan dan macet dari total kredit secara keseluruhan maka bank tersebut mengalami kredit bermasalah. NPL yang tinggi dapat mengindikasikan jumlah kredit yang bermasalah. Apabila kredit yang bermasalah semakin besar, akan menyebabkan kerugian pada bank. Sebaliknya, apabila rasio NPL nya rendah maka profitabilitas bank akan meningkat. NPL ditunjukkan dengan besarnya prosentase total kredit yang kurang lancar terhadap total kredit yang dikeluarkan oleh pihak ketiga bank. Inidikasi lain yang timbul akibat NPL yang tinggi adalah bank mengalami kerugian, maka kinerja bank juga akan semakin menurun yang akan memperngaruhi efisiensi bank.

\section{Pengaruh Kapitalisasi Terhadap Efisiensi Kinerja Perbankan}

Hasil uji Independent t-test pada tabel2didapatkan nilai $\mathrm{t}$ hitung untuk variabel Kapitlisasi terhadap efisiensi ialah nilai $\mathrm{t}$ hitung $=$ 0,557 dan nilai signifikansi sebesar $0,578>$ 0,05.Dengan demikian diperoleh bahwa kapitalisasi tidak memiliki pengaruh terhadap efisiensi. Oleh karena itu,hipotesis 5 yang menyatakan kapitalisasi berpengaruh positif terhadap efektifitas kinerja perbankan ditolak.Hasil penelitian ini sejalandengan penelitianPermana (2015) bahwa kapitalisasi tidak memiliki pengaruh terhadap efisiensi kinerja perbankan. Artinya kapitalisasi bank yang tinggi tidak menjamin bahwa bank tersebut akan efisien. Hal ini terjadi karena bank tidak bisa menghasilkan output yang optimal dengan modal yang dimiliki. Bisa karena faktor dari pengelolaan manajemen bank sehingga tidak mendapat kepercayaan masyarakat atau karena bank tersebut tidak dapat memutarkan aset yang ada sehingga terjadi pengendapan uang. 


\section{Jurnal Akuntansi dan Pajak, 20(02), 2019, 240}

Kapitalisasi pasar atau nilai pasar yang diperoleh suatu bank atau perusahaan bersumber dari hasil perkalian antara saham yang beredar dipasaran dan harga saham yang telah ditentukan masing-masing perusahaan. Hasil perkalian ini menggambarkan perusahaan melalui nilai perusahaan dari harga yang ada dipasaran. Hasil ini dapat dijadikan indikator sebagai pembanding nilai antar perusahaan. Jika bank tidak memiliki eksistensi di masyarakat, besar kemungkinan nilai pasar yang diberikan tidak akan tinggi, sehingga bank tidak dapat beroperasi dengan baik yang menyebabkan bank tersebut tidak bisa efisien karena tidak bisa bersaing.

\section{Kesimpulan}

Berdasarkan hasil analisis data dan pembahasan dalam penelitian ini dapat disimpulkan sebagai berikut:

1. Ukuran bank tidak memiliki pengaruh terhadapefisiensi bank. Hal ini menunjukkan bahwa, tidak semua perbankan dapat memiliki tingkat efisiensi yang baik dengan kepemilikan aset yang besar.

2. Capital Adequacy Ratiomemiliki pengaruh negatif terhadap tingkatefisiensi bank.Hasil ini mengindikasikan bahwa bank dengan CAR yang tinggi akan menurunkan tingkat efisiensi bank.

3. Loan to Deposit Ratio memiliki pengaruh positif yang signifikan terhadap efisiensi bank.Artinya, bank dengan LDR yang tinggi akan meningkatkan nilai efsiensi bank. Sebaliknya, LDR yang rendah akan menurunkan tingkat efisiensi bank.

4. Non Performing Loanmemiliki pengaruh negatif yang signifikan terhadap tingkatefisiensi bank. Bank dengan NPL yang tinggi akan menurunkan tingkat efisiensi. Sedangkan NPL yang rendah akan meningkatkan tingkat efisiensi

5. Kapitalisasi pasar bank tidak memiliki pengaruhterhadapefisiensi bank.

\section{Daftar Pustaka}

Asiyah, S., \& Wahyudi, S. (2014). Syariah Dan Perbankan Konvensional Dengan Metode Data Envelopment Analysis (DEA). 3, 1-10.

Berger, A. N., \& Mester, L. J. (1997). Inside the Black Box: What Explains Differences in the Institutions?

Hidayat, A. (2018). Penjelasan dan Tutorial Regresi Berganda. Statistikian.com. Retrieved from https://www.statistikian.com/2018/01/penjelasa n-tutorial-regresi-linear-berganda.html
Ismail, F., Majid, M. S. A., \& Rahim, R. A. (2013). Efficiency of Islamic and conventional banks in Malaysia. Journal of Financial Reporting and Accounting.

Muazaroh, Eduardus, T., Husnan, S., \& Hanafi, mamduh M. (2012). Determinants Of Bank Profit Efficiency : Evidence From Indonesia. 4 (2), 163-173.

Muharam, H., \& Pusvitasari, R. (2015). Analisis Perbandingan Efisiensi Bank Syariah di Indonesia Dengan Metode Data Envelopment Analysis. (December 2007).

Muljawan, D., Hafidz, J., Astuti, R. I., \& Oktapiani, R. (2014). Faktor-Faktor Penentu Efisiensi Perbankan Indonesia Serta Dampaknya Terhadap Perhitungan Suku Bunga Kredit.

Nurwulan. (2010). Analisis Pengaruh Bank SIZE, NPL, ROA, Kapitalisasi, dan CAR Terhadap Efisiensi Perbankan. 1-26.

Oktavianti, S. (2015). Pengaruh Ukuran Perusahaan, Modal Kerja, Arus Kas Terhadap Likuiditas (Studi Pada Perusahaan Manufaktur Sektor Industri Barang Konsumsi Yang Terdaftar Di Bursa Efek Indonesia Periode 2009-2013).

Permana, F. Y. (2015). Analisis Faktor-Faktor Yang Mempengaruhi. 4, 1-14.

Perwitaningtyas, G. A., \& Pangestuti, I. R. D. (2015). Faktor-Faktor Yang Mempengaruhi Efisiensi Bank Di Indonesia Periode Tahun 2008-2012. 4, 1-14.

Pratikto, H. (2011). Kinerja Efisiensi Bank Syariah Sebelum dan Sesudah. (2).

Raharjo, D. P. A., Setiaji, B., \& Syamsudin. (2014). Pengaruh rasio car, npl, ldr, bopo, dan nim terhadap kinerja bank umum di indonesia. (2005), 7-12.

Ramly, A. R., \& Hakim, A. (2017). Pemodelan Efisiensi Bank di Indonesia; Perbandingan Antara Bank Syariah dan Bank Konvensional. 7 (April), $131-148$. https://doi.org/10.15408/ess.v7i2.

Setiawan, S. (2016). Ini Insentif Dari OJK Untuk Bank Yang Tingkatkan Efisiensi. Kompas.com.

Surifah. (2011). Kepemilikan ultimat, tingkat risiko, efisiensi dan kinerja industri perbankan di indonesia. (3).

Zikiri, wa ode salama. (2017). Analisis Faktor Faktor Yang Mempegaruhi Efisiensi Perbankan Syariah Indonesia Menggunakan Data Envelopment Analysis (DEA). 